Ilona ŻEBER-DZIKOWSKA

IB UH-P Kielce

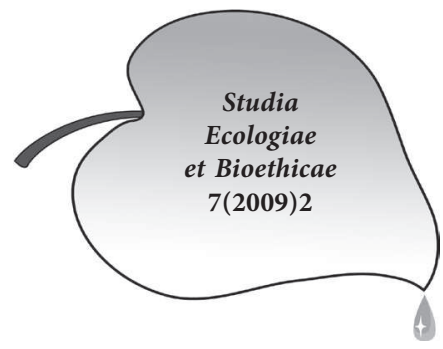

\title{
Czym jest edukacja biologiczna w wychowaniu człowieka?
}

Próbując odpowiedzieć na pytanie, które zawarte jest w tytule poniższego artykułu warto zastanowić się czym jest wychowanie w szerokim tego słowa znaczeniu i kto za nie odpowiada?

Dziecko, które pojawia się na świecie, w pierwszych dniach swojego życia nie jest świadome nawet własnego istnienia. $Z$ biegiem czasu poznaje swój organizm i prawa nim rządzące. Zdobywa umiejętności, dzięki którym może wypełniać podstawowe czynności życiowe. Wchodząc w relacje z otoczeniem, zdobywa doświadczenie życiowe. To ono wpływa na kształtowanie się charakteru dziecka oraz poczucia własnej wartości. Młody człowiek odnajduje swoje miejsce na świecie, dzięki czemu potrafi spełniać role, które stawia przed nim życie. Dochodzi do zrodzenia się systemu poglądów i wartości, które ulegając przemianie w toku życia, będą stanowily punkt odniesienia w jego postępowaniu wobec świata, ludzi i samego siebie, a także jego mądrość życiową oraz priorytety. Przemiany, którym podlega w ciągu swego życia można nazwać jego rozwojem. Oczywistym jest, że dziecko nie jest $\mathrm{w}$ stanie od momentu narodzin pokierować nim samodzielnie, ponieważ nie posiada żadnych wiadomości, ani żadnych umiejętności. Warto uświadomić sobie: co lub kto oraz w jaki sposób kształtuje osobowość człowieka, odpowiadając za jego wychowanie.

Na przestrzeni wieków poziom życia ludzkości rozwinął się zadziwiająco. Człowiek nauczył się bardzo dużo. $\mathrm{Z}$ istoty prymitywnej przeobraził się w samodzielną i inteligentną jednostkę, która współcześnie w gromadzie radzi sobie niemalże idealnie. Jako człowiek pierwotny nie potrzebował wiele do życia, aby stać się akceptowalną społecznie jednostką. Wystarczyło, że nauczył się zdobywać pożywienie, zapewnić sobie dach nad głową. Wystarczyło, że umiał przeżyć i zachować ciągłość istnienia. W tym celu musiał wpoić najczęściej doświadczalnie zdobyte zasady życia także swojemu potomstwu. Rozwijając się, z biegiem czasu, człowiek doskonalił normy wychowawcze, nie zastanawiając się nad tym zbytnio.

Początkowo wychowanie traktowane było dość wąsko. Rozumiano przez nie, nie wpojenie zasad moralnych potrzebnych na całe życie, ale raczej zapewnienie bytu $\mathrm{w}$ okresie, w którym młoda osoba nie jest $\mathrm{w}$ pełni samodzielna. 
„Etymologicznie, czyli ze względu na słowo-twórczą budowę wyrazu, „wychowanie” $w$ języku polskim pierwotnie znaczyło tyle, co „żywienie, utrzymanie”, to co dziś zawiera się w chowie (hodowli) zwierząt wyrażaniu „dobrze chować kogoš", czyli dobrze odżywiać." Do dziś tak rozumiane zapewnienie bytu stanowi podstawę wychowawczych obowiązków względem dziecka, które pojawia się na świecie, jako zupełnie niesamodzielna funkcjonalnie istota. Początkowo nie wie nawet jak żyć, ponieważ nic nie rozumie, nie potrafi myśleć, a kwintesencję jego błogiego wówczas życia stanowi dziecięce odczuwanie. Nonsensem jest więc świadome wypełnianie podstawowych czynności życiowych, charakterystyczne dla istoty ludzkiej. Dziecko nie potrafi chodzić, komunikować się z innymi ludźmi, dbać o siebie i najbliższych. Wymaga całkowitej opieki do momentu opanowania tych i innych podstawowych czynności życiowych, a później pełnego usamodzielnienia się.

„Dopiero w XIX wieku wychowanie nabiera przenośnego znaczenia, zastępując łacińską edukację." Widzimy, że obejmuje nie tylko naukę zaopiekowania się sobą w sensie fizycznym, czy problem komunikacji ze światem w sensie czysto werbalnym, ale także wprowadzenie w życie, swego rodzaju naukę życia, w czasie której dziecko stanie się posiadającym własny system wartości człowiekiem. W trakcie realizacji procesu wychowawczego młody człowiek nie tylko otrzymuje podstawy do życia, które niegdyś traktowano jako jedyne i wystarczające elementy wychowania. Niewątpliwie najważniejsze wydaje się pożywienie, ubranie, zapewnienie lokum i opieki. Istnieje jednak jeszcze w aspekcie wychowania kwestia stworzenia poczucia bezpieczeństwa, umożliwienie rozwoju osobowości dziecka, nauka odpowiedzialności za własną osobę, czy wprowadzenie w codzienność i wskazanie odpowiedniej drogi życiowej. To ważny proces stawania się człowiekiem, który powinien być umiejętnie pokierowany, nie powinien być przypadkowy. „Wychowywać to znaczy rozumnie wprowadzać dziecko w otaczający je świat, ukazywać mu w nim cele i wartości, nadawać właściwy kierunek jego życiowej aktywności oraz umiejętnie modulować i organizować wpływy pochodzące z zewnątrz."3 Na pojęcie wychowania składa się „wszystko, co wiąże się z kształceniem, samokształceniem, nauczaniem, samouctwem i nie tylko to. Wychowanie obejmuje mianowicie wszystko, co dotyczy stosunku wychowawczego między wychowankiem (...) a wychowawcą (...), co prowadzi do pożądanych w założeniu zmian w wychowanku."

$\mathrm{W}$ dzisiejszych czasach poziom rozwoju, który przedstawia swoją osobą człowiek, jest bardzo istotny. Ludzie, w których wychowanie, włożona została mądrość życiowa innych ludzi oraz ich praca i cierpliwość, dobrze radzą sobie w życiu.

\footnotetext{
1 S. Kunowski, Podstawy wspótczesnej pedagogiki. Wydawnictwo Salezjańskie, Warszawa 1993, s. 165.

2 Tamże, s. 166

H. Muszyński, Rodzina Moralność Wychowanie. Nasza Księgarnia, Warszawa 1971, s. 230.

4 W. OкоŃ, Wszystko o wychowaniu. Wydawnictwo Akademickie „Żak”, Warszawa 1999, s. 7.
} 
Wychowanie młodego człowieka oparte być powinno na „pozytywnych wzorcach i ideałach. Dzieciom powinno się wpajać, że ponad ich własnymi potrzebami istnieją takie wartości, jak współpraca, uprzejmość, uczciwość i tolerancja. Dzięki temu wychowamy ludzi chętnie pomagających innym, dążących do poprawy stosunków międzyludzkich i do budowy bezpieczeństwa światowego." ${ }^{5}$ Człowiek powinien umieć dogadywać się z innymi ludźmi i czerpać radość z kontaktów z nimi oraz z tego co robi, ponieważ tylko pełna satysfakcja $\mathrm{z}$ własnego życia daje spełnienie. Jeżeli z procesu wychowawczego wyniesiemy i wpoimy w naszą osobowość jak najlepsze cechy, tym barwniejsze i bardziej udane będzie nasze życie. Wychowanie opiera się nie tylko na żywieniu, ale także na szeregu innych, bardziej złożonych czynności wychowawczych, które mają przygotować młodego człowieka do funkcjonowania w otaczającym go świecie. Czynności te obejmują strefę rozwoju osobowości człowieka, która zmienia się w toku życia i rozwoju osobniczego jednostki. Charakter i wartości, które wykształciły się u młodego człowieka w ciągu całego życia ulegają przemianom na wielu płaszczyznach, uzyskując poziom coraz bardziej dojrzały i stabilny, czasem niezmienny. Wychowanie „jest utożsamiane z oddziaływaniem na psychikę i zachowanie człowieka, przy czym przez oddziaływanie to rozumie się szczególnie wywieranie wpływu na zmiany czy przeobrażenia w osobowości i zachowaniu, zwłaszcza opinii i przekonań o otaczającym świecie oraz postaw wobec ludzi, samych siebie i wartości." ${ }^{\prime}$ Nabywanie tych i innych umiejętności w procesie wychowawczym wpływa na kształtowanie osobowości człowieka. Wychowanie „... jest utożsamiane z rozwijaniem (kształtowaniem) osobowości pod względem wszystkich jej cech.”7 Można powiedzieć, że „przez wychowanie rozumie się nade wszystko kształtowanie charakteru jednostki." ${ }^{8}$

Niewątpliwie kształtowanie się osobowości, czy charakteru ma miejsce od najwcześniejszych dni życia. Środowisko życia stanowi wówczas rodzina, czyli rodzice, rodzeństwo, dziadkowie, czasem inne, niekoniecznie spokrewnione $\mathrm{z}$ dzieckiem osoby, znajdujące się $\mathrm{w}$ jego otoczeniu. To „... rodzina stanowiła zawsze pierwsze środowisko wychowawcze." Narodziny nowego członka rodziny to zazwyczaj niezwykle istotne wydarzenie w życiu każdego rodzica. Towarzyszy mu wielkie napięcie, oczekiwanie, radość i nadzieje, które pokłada w swojej pociesze, mimo jej młodego wieku. Rodzice od samego początku myślą o tym, jak wiele chcieliby nauczyć swoje maleństwo i jak daleko ono pod ich okiem zajdzie,

5 B. Spock, M. Rothenberg, Dziecko. Pielegnowanie i Wychowanie. Wydawnictwo Lekarskie PZWL, Warszawa 1990, s. 15.

6 M. ŁовоскI, ABC Wychowania. Wydawnictwo Uniwersytetu Marii Curie-Skłodowskiej, Lublin 1999, s. 11.

7 S. Kunowski, Podstawy współczesnej pedagogiki. Wydawnictwo Salezjańskie, Warszawa 1993, s. 19.

8 M. Łовоскі, Teoria Wychowania w zarysie. Oficyna Wydawnicza „Impuls”, Kraków 2006, s. 32.

9 Z. Giereluk-Lubowicz, Wychowanie w rodzinie wielkomiejskiej. WSiP, Warszawa 1978, s. 13. 
jak wiele osiągnie. Chcą dać dziecku jak najwięcej z siebie i jak najwięcej z otoczenia. Opiekują się nim najlepiej jak potrafią. „Najogólniej można powiedzieć, że wychowanie i opieka są pojęciami bliskoznacznymi”" ${ }^{10}$, we wszystkich czynnościach opiekuńczych odbywa się akt wychowawczy. Opieka obejmuje sprawowanie bezpośredniej kontroli nad bezpiecznym rozwojem dziecka, zapewnienie mu poczucia bezpieczeństwa i jak najlepszych możliwości podczas nauki chodzenia, mówienia, czy w ogóle podczas zdobywania informacji o świecie. Rola rodziców jako opiekunów jest niezwykle ważna. To pod ich czujnym okiem dorastający człowiek nabywa koniecznego $\mathrm{w}$ dalszym prawidłowym funkcjonowaniu poczucia bezpieczeństwa. Zazwyczaj taka opieka realizowana jest przez całe życie, ponieważ ludzie, którzy wiele sobie zawdzięczają, nie zrywają ze sobą kontaktów i wspierają się przez całe życie. Kiedy w rodzinie panuje miłość, pomimo tego, że jednostka dorosła i założyła własną rodzinę, nadal może czuć nad sobą opiekę, a przede wszystkim wsparcie ze strony najbliższych.

Wychowanie nie trwa tak długo, gdyż kończy się w momencie ukształtowania osobowości człowieka. Okres wychowania w obecnych czasach wydłuża się jednak, gdyż „powszechne staje się wykształcenie średnie, zwiększa się także z roku na rok liczba młodzieży studiującej w wyższych uczelniach. Coraz później zatem jednostka usamodzielnia się całkowicie i przestaje podlegać oddziaływaniom rodziny (...), która czuje się za nią odpowiedzialna przynajmniej przez cały okres kształcenia i przygotowania do zawodu"11. To właśnie członkowie rodziny, stanowiący najbliższe otoczenie, są dla dziecka pierwszym autorytetem na ścieżce życia, uczestniczą w jego wychowaniu. „Wszystkim dzieciom ich rodzice ukazują się początkowo jako pewnego rodzaju bóstwo. Ta różnica w „psychologicznej wielkości” istnieje nie tylko dlatego, że dzieci widzą swoich rodziców jako większych i mocniejszych, ale również jako mądrzejszych i dzielniejszych." ${ }^{\prime 2}$ Stąd wiara dzieci w nieomylność i niekończącą się wiedzę rodziców. „Wychowanie jest zawsze społecznie uznanym systemem działania pokoleń starszych na dorastające celem pokierowania ich wszechstronnym rozwojem dla przygotowania według określonego ideału nowego człowieka do przyszłego życia."13 Najbliżsi przekazują młodemu człowiekowi swoje wartości i przekonania, uznając je za najlepsze. Dziecko rozwija się, początkowo nieświadomie, za wzór stawiając sobie rodziców lub innych członków rodziny. Powiela ich zachowania i uczy się różnych zachowań w konkretnych sytuacjach wykorzystując rady najbliższych. O roli rodziny, jako naturalnego środowiska życia i wychowania świadczy fakt, że stanowią pierwsze źródło przekazu wszelkich sym-

\footnotetext{
10 M. Łовоскі, ABC Wychowania. Wydawnictwo Uniwersytetu Marii Curie-Skłodowskiej, Lublin 1999 , s. 20

11 M. Przetacznikowa, Z. WŁodarski, Psychologia Wychowawcza. Państwowe Wydawnictwo Naukowe, Warszawa 1979, s. 440.

12 T. Gordon, Wychowanie bez porażek. Instytut Wydawniczy Pax, Warszawa 2007, s. 157.

13 S. Kunowski, Podstawy wspótczesnej pedagogiki. Wydawnictwo Salezjańskie, Warszawa 1993, s. 170.
} 
boli, za pomocą których dziecko zaczyna porozumiewać się z otoczeniem i dzięki którym nawiązuje z nim kontakt. To rodzina stanowi podstawowe środowisko życia i wychowania młodego pokolenia.

„Rozwój psychospołeczny młodego człowieka wyznaczony jest przede wszystkim przez całokształt stosunków panujących w rodzinie oraz przez organizację życia w niej." ${ }^{\prime 4}$ Dziecko obserwując zachowania członków rodziny, powiela je. Bardzo istotne stają się relacje pomiędzy poszczególnymi członkami rodziny, którzy w różnym stopniu są dla wychowanka ważni, zyskują w jego oczach miano autorytetu. To od nich dziecko uczy się odczytywać emocje i budować więzi z innymi osobami, uczy się radości życia, ale ucząc się odczuwać, przejmuje także zachowania negatywne, dlatego tak ważny jest stosunek i nastawienie najbliższych do życia i siebie nawzajem. Młody człowiek powinien nauczyć się radzić sobie ze swoimi emocjami. Nie wystarczy, że najbliżsi powiedzą jak to robić. Niezmiernie ważny jest przykład, który dają dziecku własną osobą. Ważne jest, aby pokazać wychowankowi, że negatywne emocje nie są złe. Należy tylko umieć sobie z nimi radzić. W każdej sytuacji życiowej, która stanie przed dzieckiem, będzie ono szukało autorytetu w najbliższych, nawet jeśli czasem wydawać by się mogło, że po prostu chce tylko postawić na swoim. „W dobrze zorganizowanej pod względem wychowawczym rodzinie nie trzeba poświęcać wiele uwagi, czasu i wysiłku na odrębne „wychowanie” dzieci. Ich psychikę, bowiem kształtuje wszystko, co stanowi treść i formy życia rodzinnego: i to, jak domownicy odnoszą się nawzajem do siebie, i to, czym się cieszą, a czym się martwią, i to, jakich zasad przestrzegają w swym postępowaniu, a wreszcie i to, co jest dla nich naprawdę święte i drogie." ${ }^{\prime 15}$ Nowy członek rodziny, dorastając w rodzinie, uczy się panujących w niej zwyczajów, ale jednocześnie w jakimś stopniu zachowuje swój własny, niepowtarzalny charakter, który musi zostać w rodzinie niejako przyjęty i zaakceptowany. Akceptacja ta ma charakter obustronny. Kiedy powielając zachowania człowiek kształtuje swój charakter, w pewnym momencie zaczyna dostrzegać niedoskonałości swoich najbliższych oraz różnice w charakterze i pragnieniach własnej osoby w odniesieniu do postaw członków rodziny. Wówczas mając na uwadze wartości, które dzięki nim przyswoił i szacunek, którym ich darzy, będzie doskonalił umiejętność współżycia $\mathrm{w}$ tej rodzinie $\mathrm{z}$ uwzględnieniem różnic w osobowości pozostałych jej członków. „Rzeczywiste wychowanie w rodzinie może polegać jedynie na doskonaleniu wewnętrznego życia w niej"16 czy też nauce „samodzielnego i intensywnego zajmowania się określonym zadaniem. (...) Kto w odpowiedni sposób nie stawia umiejętnościom dziecka wymagań, które będą dla niego wyzwaniem, nie pobudza rozpoznawalnych u niego zainteresowań albo

\footnotetext{
14 H. Muszyński, Rodzina Moralność Wychowanie. Nasza Księgarnia, Warszawa 1971, s. 175.

15 Tamże, s. 175.

16 Tamże, s. 177.
} 
nie próbuje obudzić w nim nowych" ${ }^{17}$. Bez wątpienia można stwierdzić, że „nic i nikt nie może zastąpić rodziny we współczesnym świecie"18.

Jakże miło dorastać i uczyć się w kochającej, przepełnionej miłością rodzinie. Zwykle wychowanie w rodzinie nie odbywa się na drodze zamierzonego i zaplanowanego procesu, ale jest ciągiem spontanicznie następujących zmian kształtującego się człowieczeństwa jednostki ludzkiej. „Ostatnio w wielu definicjach wychowania akcentuje się nie tyle wywieranie bezpośredniego wpływu na wychowanków, ile wspomaganie ich w naturalnym i spontanicznym rozwoju... Zgodnie z tym postulatem, wychowywać oznacza wyzwalać, dodawać uwagi, uwalniać od ubezwłasnowolnienia, usuwać wpływy zagrażające naturalnemu i spontanicznemu rozwojowi dzieci i młodzieży, przygotowywać ich do przyszłego życia przez mobilizację do własnej aktywności, pobudzać do zachowań zgodnych z oczekiwaniami społecznymi, zasadami moralności, a także etyki normatywnej. W zrozumianym $\mathrm{w}$ ten sposób wychowaniu podkreśla się doniosłe znaczenie współdziałania i współpracy pomiędzy wychowawcą i wychowankiem, a nade wszystko rolę ich wzajemnego porozumiewania się $\mathrm{w}$ warunkach autentycznego partnerstwa i demokratyzmu." ${ }^{19}$ Takie relacje nietrudno osiągnąć, gdy między członkami rodziny istnieje miłość, szacunek i otwarcie na uczucia, na to, co druga osoba ma do przekazania. Rodzice, którzy będą szanować indywidualizm własnego dziecka, wykreują w nim potrzebę akceptacji dla ich inności. Chociaż „wszyscy rodzice mają jakieś cele wychowawcze i pragną je osiągnąc ${ }^{\prime 20}$ to przede wszystkim wzajemne zrozumienie i zaufanie oraz dobry przykład są podstawami do nauki odpowiedzialności młodego człowieka. Dzięki niej możliwe jest pewnego rodzaju usamodzielnienie jednostki. Może ona, dostając od najbliższych jedynie wsparcie, podejmować początkowo błahe, później coraz to poważniejsze odnośnie samej siebie. Ważne jest, aby w odpowiednim wieku dziecko miało wpływ na własny rozwój, np. przez kształtowanie pod okiem rodziców własnych zainteresowań, ponieważ proces wychowania „...polega nie tylko na dyrektywnym kierowaniu rozwojem wychowanka, ale przede wszystkim na wspieraniu go w kierowaniu własnym rozwojem." ${ }^{21}$ Dziecko powinno czuć, że jest odpowiedzialne za siebie od najwcześniejszych lat. Chociaż prawnie i moralnie to rodzice sprawują nad nim kontrolę, młody człowiek ma prawo decydowania lub współdecydowania o sobie, uczenia się ponoszenia konsekwencji własnego postę-

17 P. Pauling, Szczesśliwe Dzieci, czyli udane wychowanie. Wydawnictwo „Jedność”, Kielce 2000, s. 43.

18 D. Siemek, Problemy Wychowawcze Wieku Dorastania. Instytut Wydawniczy Związków Zawodowych, Warszawa 1986, s. 84.

19 M. Łовоскі, ABC Wychowania. Wydawnictwo Uniwersytetu Marii Curie-Skłodowskiej, Lublin 1999, s. 12.

20 P. Pauling, Szczéśliwe Dzieci, czyli udane wychowanie. Wydawnictwo „Jedność”, Kielce 2000, s. 47.

21 Red. M. Łовоскі, Praca wychowawcza dziećmi i młodzieża. Wydawnictwo Uniwersytetu Marii Curie-Skłodowskiej, Lublin 1998, s. 7. 
powania, po to, aby w dorosłym życiu potrafił być pełnym bogatych zasad wychowawczych panem swojego losu.

Widzimy, że rodzina wychowując, przygotowuje do życia, w każdym tego słowa znaczeniu. „Bez tej skomplikowanej i uciążliwej pomocy wychowawczej tak w dziedzinie fizycznej (żywienie, higiena), jak psychicznej (kształcenie umysłowe i moralne) oraz duchowej (działanie uszlachetniające sztuki i religii) młody człowiek nie może się w pełni rozwinąć. Koniecznością więc biologiczną jest niesienie pomocy wychowawczej dla prawidłowego ukształtowania człowieka, co razem ujmowane bywa w pojęciu wychowania."22 Jednak nie tylko rodzina kształtuje osobowość i charakter młodego człowieka. Szczególną rolę w kształtowaniu postaw dzieci i młodzieży, prócz rodziny, odgrywa grupa rówieśnicza, „jako niewielka liczba osób pozostających ze sobą w bezpośrednich kontaktach i mających poczucie swej odrębności grupowej oraz wspólnie podzielane wartości." ${ }^{23}$ Rówieśnicy, z którymi dziecko może nawiązać kontakt jeszcze przed pójściem do szkoły niejednokrotnie mogą przejąć rolę członków rodziny w byciu autorytetem. Wiadomo, że dziecko potrzebuje kontaktu z drugim dzieckiem. Nic nie zastąpi wspólnych gier i zabaw, wzajemnego naśladowania, które niejednokrotnie przeistacza się w przyjaźń na całe życie. W okresie dzieciństwa bardzo łatwo chłonie się nawyki rówieśników, traktując je, jako takie cudowne, bo najczęściej nowe i inne od tych, których nauczyli rodzice. Taki wpływ rówieśników na dziecko niekoniecznie jest zjawiskiem pozytywnym, ale nieuniknionym.

Wśród czynników wywierających znaczący wpływ na psychikę i zachowanie się dzieci i młodzieży pozostają niewątpliwie, prócz niezamierzonych wpływów środowiska rówieśniczego i lokalnego, środki masowego przekazu. Rodzice czy opiekunowie nie zdają sobie sprawy jak duży wpływ na kształtowanie osobowości ich dziecka mają prasa, książki, radio, telewizja, czy Internet. Zdarza się, że dziecko pozostawione samo sobie, czyli bez bezpośredniego kontaktu z najbliższymi, mając poczucie osamotnienia, braku zainteresowania, szuka odpowiedzi na nurtujące go pytania w środkach masowego przekazu. Takie rady mogą być cenne, ale na pewno nie zaspokoją potrzeby bliskości zaufanej osoby i nie dadzą pewności, że w razie porażki można liczyć na pomoc, wsparcie. Na szczęście istnieją także odpowiednie placówki, które pomagają rodzicom w procesie wychowawczym, a niejednokrotnie wyręczają ich w jego realizacji. Do instytucji opiekuńczo-wychowawczych zalicza się przedszkola, szkoły, internaty, domy dziecka, pogotowia opiekuńcze, domy kultury i inne. Nie bez znaczenia jest tu działalność innych, wspomagających rozwój, a przez co i proces wychowawczy, placówek, takich jak place zabaw, świetlice, biblioteki, teatry, itp. Dzięki takim instytucjom

22 M. Łовоскі, ABC Wychowania. Wydawnictwo Uniwersytetu Marii Curie-Skłodowskiej, Lublin 1999, s. 12.

23 Tamże, s. 43. 
młody człowiek może się w pełni rozwijać. Zdobywa nie tylko wiedzę, ale także inwestuje w sferę duchowości. Wzbogaca swoją wyobraźnię, wrażliwość, podnosi poziom swojego intelektu. Widzimy jak ważny jest udział w kulturalnym życiu otoczenia i nie tylko. „Proces rozwojowy wychowanka... może być niezamierzonym skutkiem pośredniego działania innych ludzi, bądź też może się odbywać pod bezwiednym wpływem warunków społecznych otoczenia ze stanem rozwojowym samego wychowanka"24, w którym uczestniczą $\mathrm{m}$. in. wyżej wymienione zakłady społeczne, oświatowe i kulturalne.

Widzimy, że nie zawsze wychowanie jest tylko niezamierzonym wpływem czynników, czy osób z zewnątrz. Przecież już rodzice wiedzą, czego chcą dla swego dziecka. Mamy więc do czynienia z działaniem wychowawczym, które ma charakter procesu mniej lub bardziej zaplanowanego, ponieważ starają się oni wychować swoją pociechę. Charakter wychowania, jako procesu przemyślanego i zorganizowanego oddaje działalność wszystkich instytucji powołanych do kształtowania osobowości dzieci i młodzieży, rozwijanie ich intelektu, przygotowania do wykonywania określonego zawodu. Niewątpliwie taką rolę pełni szkoła, będąca obok rodziny i środowiska rówieśniczego, ważnym środowiskiem wychowawczym młodzieży. „Wychowanie w rodzinie, w szkole i w społeczeństwie ujmowane jako całokształt procesu rozwojowego jest zadaniem bardzo odpowiedzialnym. Pomyślny rozwój każdego człowieka zależy w istocie od zaspokojenia jego głębokich potrzeb uczuciowych w zakresie wymogów społeczeństwa, w którym wzrasta." ${ }^{25}$ „Doniosła rola rodziny i szkoły w procesie wychowania wynika $\mathrm{z}$ faktu, iż stanowią one dwa podstawowe środowiska wychowawcze, liczące się w sposób istotny w życiu dzieci i młodzieży. Rodzina i szkoła są zazwyczaj terenem rozlicznych oddziaływań mających decydujący wpływ na rozwój umysłowy i społeczny dziecka." ${ }^{26}$ Rodzina jest instytucją naturalną, której oczywistym, ale nieprzymuszonym i bezinteresownym celem jest wychowanie w miłości narodzonego dziecka. Szkoła powinna pełnić z założenia także rolę wychowawczą. Jednak w tym przypadku w grę wchodzi nieco poważniejsza kwestia, bo prócz opieki, także sprawa rozwinięcia zainteresowań, a nade wszystko kwestia wykształcenia. Szkoła pomóc powinna w wyborze własnej drogi życiowej każdego wychowanka i pokierować rozwojem jego osobowości w drodze do kariery. „Współdziałanie nauczycieli i rodziców jest jednym z istotnych czynników prawidłowego funkcjonowania szkoły i rodziny. Warunkuje harmonijny rozwój uczniów. Wpływa zarówno na ich postępy w nauce, jak

\footnotetext{
${ }_{24}$ S. Kunowski, Podstawy współczesnej pedagogiki. Wydawnictwo Salezjańskie, Warszawa 1993, s. 170 .

25 W. D. Wall, Wychowanie i Zdrowie Psychiczne. Państwowe Wydawnictwo Naukowe, Warszawa 1960, s. 15.

26 M. Łовоскі, Współdziałanie nauczycieli i rodziców w procesie wychowania. Nasza Księgarnia, Warszawa 1985, s. 11.
} 
i w zachowaniu." ${ }^{27}$ Uczeń powinien widzieć i czuć, że zarówno rodzina jak i szkoła wspierają jego rozwój, dają mu poczucie bezpieczeństwa i pomagają osiągnąć to, czego pragnie.

Pod wpływem świadomego i celowego oddziaływania odpowiedzialnych za wychowanie osób i instytucji kształtuje się proces wychowania oraz uwidaczniają się jego wyniki. W przypadku szkoły wyniki wychowawcze są dobrze widoczne na dwóch poziomach. Pierwszym jest zachowanie, na które wpływ początkowo mają rodzice. $\mathrm{W}$ dalszej kolejności bardzo wyraźnie zaznacza się wpływ na ten aspekt wychowania szkoły, ale także innych instytucji i osób. Drugim jest poziom intelektualny, który dzięki włożonej pracy pedagogów osiągają wychowankowie. W pierwszej kolejności należy zwrócić uwagę na wiedzę uczniów, w dalszej na ich umiejętności z określonych dziedzin. Wiadomo, że nie tylko zdobywanie wiedzy stanowi w tym aspekcie element wychowania. Istotny jest przede wszystkim rozwój, który dotyczy uczniów mających kontakt z różnymi dyscyplinami wiedzy. „Jednym z głównych celów stosowania proponowanych form pracy wychowawczej w szkole jest stworzenie warunków sprzyjających uczniom w ich własnym rozwoju emocjonalnym, społecznym i umysłowym." ${ }^{28}$ Jest to w pewnym sensie kontynuacja procesu, który powinni zapoczątkować rodzice, bądź opiekunowie, gdyż to pod ich okiem dziecko zdobywa podstawy do rozwoju swojego człowieczeństwa. Później już tylko kształtuje się jego intelekt, światopogląd. Człowiek rozwija swoją inteligencję emocjonalną, której poziom w ogromnym stopniu odzwierciedla się w późniejszych kontaktach społecznych. „Przede wszystkim mówiąc o wychowaniu, myślimy o działalności wychowawczej, powodującej stawanie się mądrzejszym i lepszym." ${ }^{29}$ Taki przecież jest cel wychowawczy. Liczy się wyprowadzenie młodego człowieka na dobrą i mądrą osobę, która zdobywając nowe doświadczenia życiowe będzie potrafiła wykorzystać je w przyszłości. „Mówiąc o stawaniu się młodzieży szkolnej mądrzejszą myślimy o:

1) działaniu wychowawczym, czyli czynnościach wychowawców;

2) warunkach, okolicznościach i bodźcach, czyli sytuacjach wychowawczych;

3) wyniku, czyli wytworze wszystkich działań i warunków;

4) zachodzących zmianach, a więc o całkowitym procesie wychowawczego rozwoju człowieka" ${ }^{30}$ (zmienione).

W szkole uczeń, uczestnicząc w lekcjach wychowawczych, zajęciach przedmiotowych oraz pozalekcyjnym życiu szkoły, ma ku temu okazje. Biorąc pod uwage jego

27 M. Łовоскі, Współdziałanie nauczycieli i rodziców w procesie wychowania. Nasza Księgarnia, Warszawa 1985, s. 7.

28 M. Łовоскі, W poszukiwaniu skutecznych form wychowania. Wydawnictwa Szkolne i Pedagogiczne, Warszawa 1990, s. 17.

29 M. ŁовоскI, $A B C$ Wychowania. Wydawnictwo Uniwersytetu Marii Curie-Skłodowskiej, Lublin 1999, s. 12.

30 S. Kunowski, Podstawy wspótczesnej pedagogiki. Wydawnictwo Salezjańskie, Warszawa 1993, s. 19. 
możliwości, zauważamy, że postęp rozwojowy, jaki osiąga, w szkole jest największy. Zapewne dzieje się tak ze względu na wiek. Młoda osoba szybciej uczy się nowych rzeczy i lepiej potrafi z nich korzystać. Jest to jednak także zasługa otoczenia. Rówieśnicy i atmosfera wpływają na to, że poszerzanie wiedzy staje się dużo przyjemniejsze. Jeżeli dojdzie do tego pozytywne nastawienie dziecka do szkoły, które najczęściej w dużej mierze zależy od rodziców, możliwości rozwojowe jednostki bardzo wzrastają. „W szkole młodzież zdobywa ciągle nowy i bogatszy zasób wiedzy, rozwija przydatne w życiu umiejętności, zdobywa doświadczenia, uczy się współżycia i współdziałania z innymi. Szkoła ułatwia rozwijanie i pogłębianie przekonań i postaw w sferze społecznej, moralnej, ideowej, religijnej. Realizacja tych celów i zadań jest możliwa przede wszystkim dzięki spełnianiu przez szkołę trzech podstawowych funkcji: dydaktycznej, wychowawczej i opiekuńczej, czyli dzięki przekazywaniu wiedzy z różnych dziedzin (funkcji dydaktyczna); dzięki kształtowaniu postaw społeczno-moralnych i ideowych (funkcja wychowawcza); dzięki zaspokajaniu potrzeb niezbędnych dla prawidłowego rozwoju fizycznego i psychicznego uczniów (funkcja opiekuńcza). Wymienione funkcje wzajemnie się uzupełniają, czyli każda z nich może być spełniona w sposób zadowalający tylko wtedy, gdy również pozostałe funkcje znajdują w miarę pełne swe urzeczywistnienie w procesie wychowania." ${ }^{31}$

Nietrudno zauważyć wychowawczy aspekt szkoły na poziomach, które realizowane są przede wszystkim, ale nie tylko, $\mathrm{w}$ domu przez rodziców i innych członków rodziny. Wychowanek rozwija się dzięki temu, że ma zapewnioną opiekę, wprowadzenie na odpowiednią ścieżkę życia oraz mocne zaplecze wiedzy, którą może pogłębiać zgodnie ze swoimi zainteresowaniami. Dostając odpowiednie podstawy i warunki do rozwijania i kształtowania swojej osobowości młody człowiek nauczy się słuchać rad, a w przyszłości samodzielnie kierować własnym rozwojem. „Istotnym warunkiem skutecznego wychowania jest bezsprzecznie podmiotowe traktowanie dzieci i młodzieży zarówno przez rodziców i wychowawców, jak i nauczycieli. Oznacza to humanistyczne do nich podejście, czyli zapewnienie im prawa do bycia w miarę samodzielnym i niezależnym, a także ponoszenia odpowiedzialności za swe postępowanie i kierowanie własnym rozwojem. Nade wszystko zaś zakłada się tu poszanowanie godności osobistej dzieci i młodzieży, czyli umacnianie w nich poczucia własnej wartości.”32 Dziecko powinno dostać od opiekunów możliwość zachowania własnej indywidualności. Musi zdawać sobie sprawę z własnej niepowtarzalności i jednocześnie czuć, że jest w pełni akceptowane przez bliskich. Nikt nie powinien narzucać mu niczego, co jest sprzeczne z jego osobą, ponieważ tylko je unieszczęśliwi. Ważne jest, aby w procesie wychowawczym, który powinien być konsekwentny, było także miejsce na samodzielne decydowanie

31 Łовоскі M. ABC Wychowania. Wydawnictwo Uniwersytetu Marii Curie-Skłodowskiej, Lublin 1999 , s. 51.

32 Red. М. Łовоскі, Praca wychowawcza z dziećmi i młodzieża. Wydawnictwo Uniwersytetu Marii Curie-Skłodowskiej, Lublin 1998, s. 16. 
wychowanka o sobie. We wczesnych etapach wychowania w grę wchodzą najprostsze sprawy, ale i ich podejmowanie jest ważne, ponieważ uczy młodego człowieka odpowiedzialności, która przyda się w dalszym życiu. $Z$ biegiem lat dziecko rozwinie w sobie odpowiedzialność i dojrzałość, stając się dumą rodziców.

Wychowawcy muszą wiedzieć, że wychowanie nie jest pojedynczym incydentem, ale ciągłym procesem. Zarówno opieka, wychowanie, jak i dydaktyczna strona procesu wychowawczego, powinny być realizowane w sposób konsekwentny i przede wszystkim ciągły. „Długotrwałość wychowania łączy się także z systematycznością. Ma to doniosłe znaczenie dla ciągłego pogłębiania i przetrwania osiągniętych wyników. Dłuższe przerwy w procesie wychowawczym niosą z sobą ryzyko nie tylko zaprzepaszczenia tego, co udało się już osiągnąć, lecz nierzadko mogą grozić także niebezpieczeństwem wyraźnego cofania się w rozwoju społeczno-moralnym wychowanków."33 Istotne wydaje się w tym przypadku prowadzenie procesu wychowawczego w sposób ciągły, szczególnie wyraźnie widoczne w skutkach przy przekazywaniu wiedzy wychowankom na przykład w szkole. Kiedy dziecko nabywa treści w sposób systematyczny i jednocześnie konsekwentnie utrwala to, co już osiągnęło, jego praca jest wyjątkowo owocna. Kiedy jednak nauka odbywa się raz na jakiś czas, a wiadomości i umiejętności nie są utrwalane przez powtarzanie, dochodzi do ich zaniku po dość krótkim czasie. W tym przypadku zdobywanie wiedzy traci sens przede wszystkim dla osoby uczącej się. Podobnie wygląda kształtowanie postaw w dorastającym dziecku, które powinno je stale obserwować i powielać w odpowiednich momentach życia.

W przypadku szkoły działalność wychowawcza wychowawców, którymi są nauczyciele, jest chyba najbardziej zaplanowana. „Wychowawca jest świadomy celów, jakie pragnie realizować $\mathrm{w}$ wyniku planowo organizowanej działalności wychowawczej." ${ }^{34}$ Świadomość roli, jaką spełnia oraz przygotowanie do wypełniania zawodu, są podstawą skutecznego oddziaływania na wychowanków. Zawiera ono w sobie nie tylko opiekę i pomoc w dalszym kształtowaniu osobowości młodego człowieka, ale także przygotowanie go do wykonywania przyszłego zawodu. W tym celu uczeń musi zdobyć, niezbędną do osiągnięcia jak najwyższego poziomu intelektualnego, wiedzę, którą będzie mógł poszerzać na dalszych etapach kształcenia. Wykształcona kadra pedagogiczna ma zapewnić uczniom możliwość zdobycia wiedzy z poszczególnych dyscyplin naukowych. W najwcześniejszych etapach kształcenia wychowankowie nabywają podstawowe umiejętności niezbędne w szkole, ale również przede wszystkim w życiu. Wraz z ich rozwojem poszerzają się ich możliwości, dzięki czemu wzrastać może poziom przekazywanej im wiedzy. Niektóre dzieci wyrastają na humanistów, inne

\footnotetext{
33 M. ŁовоскI, ABC Wychowania. Wydawnictwo Uniwersytetu Marii Curie-Skłodowskiej, Lublin 1999, s. 19.

34 Tamże, s. 15.
} 
wolą przedmioty ścisłe. To zainteresowania decydują o wyborze dalszej drogi życiowej, do której bramą często są odpowiednie studia.

Nie zapominajmy, że edukacja człowieka rozpoczyna się już w okresie jego dzieciństwa. Początkowo to rodzice wpajają dziecku niezbędne w przyszłym życiu zagadnienia, zwykle na drodze zabawy. Zaspokajają rosnącą w nim potrzebę zdobywania wiedzy, odpowiadając na liczne pytania. Uzupełniają przekazywane treści poprzez doświadczenia, na które składają się spacery, zabawy i gry edukacyjne. Następnie młody człowiek rozpoczyna edukację szkolną, która wywiera ogromny wpływ na dalsze jego życie. To tam jego dotychczasowa wiedza ulega uporządkowaniu oraz znacznemu poszerzeniu. Szkoła stwarza możliwość systematycznego zdobywania wiedzy pod czujnym i fachowym okiem pedagogów. Już w szkole podstawowej dziecko nabywa wiedzę, która podzielona jest na poszczególne dyscypliny naukowe. Początkowo szerokie bloki zagadnień ulegają dalszej specjalizacji na węższe, czyli przedmioty.

W związku z tym - czym jest edukacja biologiczna w wychowaniu człowieka?

Gdzieś po drodze edukacji dziecka, jako przedmiot pojawia się biologia, z którą młody człowiek miał już zapewne styczność pod okiem rodziców. „Nauka biologii jest bardzo ważnym elementem w edukacji młodego człowieka, pomocnym w zrozumieniu siebie i otaczającej rzeczywistości." ${ }^{35}$ Okoń definiuje biologię, jako „przedmiot nauczania szkolnego umożliwiający uczniom poznawanie żywych organizmów roślinnych i zwierzęcych, ich budowy i zachowania się, związku ze środowiskiem oraz zdobywanie umiejętności związanych $\mathrm{z}$ oddziaływaniem na przyrodę żywą i z ochroną naturalnego środowiska człowieka, jak również kształtujący naukowy pogląd na świat. Biologia w szkole obejmuje botanikę, czyli naukę o roślinach, zoologię, tj. naukę o zwierzętach, anatomię i fizjologię człowieka oraz biologię ogólną, tj. naukę o najbardziej ogólnych przejawach życia." ${ }^{36}$

Doskonale zdajemy sobie sprawę, że zanim dziecko przebrnie przez treści biologiczne, zawarte $\mathrm{w}$ podstawie programowej, będzie mogło podstawowe zagadnienia z tej dziedziny zdobyć pod okiem rodziców, a także innych osób, z którymi przyjdzie mu się zetknąć. Często sposób, w jaki rodzice i najbliżsi zainteresują dziecko zagadnieniami biologicznymi wpłynie na dalszy jego stosunek do przedmiotu. Szkoła, a dokładniej metody dydaktyczne konkretnego nauczyciela również wpłyną na naukę przedmiotu, gdyż „nie ulega wątpliwości, że w procesie wychowania i nauczania, bardziej niż w jakimkolwiek innym zawodzie, czynnik osoby odgrywa dużą rolę" ${ }^{\prime 3}$.

Trudno jednoznacznie określić jak przebiega wychowanie poprzez nauczanie biologii. „Na złożoność tego zagadnienia składają się różne aspekty, m.in.: przekazane wzorce światopoglądowe, środowisko społeczne, wychowanie rodzinne i postawy,

35 I. Żeber-Dzikowska, J. Bartoszczyk, Znaczenie nauczania biologii w kształtowaniu osobowości ucznia. Wydawnictwo Akademii Świętokrzyskiej, Kielce 2007, s. 32.

36 W. OкоŃ, Słownik Pedagogiczny. Państwowe Wydawnictwo Naukowe, Warszawa 1987, s. 33.

37 I. Żeber-Dzikowska, J. Bartoszczyк, Znaczenie nauczania biologii w ksztaltowaniu osobowości ucznia. Wydawnictwo Akademii Świętokrzyskiej, Kielce 2007, s. 7. 
zainteresowania, poziom wiedzy biologicznej, wreszcie odpowiedzialność etyczno - moralna za swoje i drugich człowieczeństwo. Trudno oddzielić nauczanie przedmiotowe od problemów wychowawczych w pracy nauczyciela, gdyż one bardzo się ze sobą wiążą." ${ }^{38}$ Zapoczątkowany przez rodzinę proces wychowawczy jest kontynuowany w czasie edukacji młodego człowieka w szkole przez nauczyciela, jednak należy pamiętać o tym, że w obu przypadkach chodzi o rozwinięcie i ukształtowanie postaw charakteryzujących osobę odpowiedzialną za siebie, innych i otaczające środowisko. „Programy kształcenia w szkołach wyższych uwzględniają wiele już bardziej szczegółowych dyscyplin biologicznych, jak np. bionika, biochemia, mikrobiologia, zoogeografia czy ekologia. Biologia w szkole, jako jeden z przedmiotów ważnych dla kształcenia politechnicznego stanowi podstawę agro- i zootechniki oraz umożliwia opanowanie niektórych narzędzi używanych w produkcji rolno-hodowlanej." ${ }^{39}$

Szeroki zakres treści biologicznych oraz krótka refleksja na temat zdobywania wiedzy z zakresu biologii pozwala zauważyć, że przedmiot ten, podobnie jak inne, kształtuje osobowość dorastającego młodego człowieka, ale jednocześnie znacznie różni się od takich przedmiotów, jak na przykład historia, czy matematyka, ponieważ ściśle i bezpośrednio dotyczy człowieka i jego funkcjonowania, będącego podstawą życia. Biologia, znacznie skuteczniej niż inne przedmioty nauczania, uwrażliwia uczniów na potrzeby człowieka oraz żywej przyrody i jej ochrony. Posiada olbrzymie zastosowanie w codziennym życiu. Od początku istnienia dziecko uczone jest własnej fizjologii, ma kontakt ze środowiskiem oraz żyjącymi w nim organizmami roślinnymi i zwierzęcymi. Pod okiem rodziców uczy się odnajdywać w świecie przyrody i stosować zasady, które w okresie edukacji na nowo pozna, jako zagadnienia biologiczne. Nie obca jest mu higiena własnego organizmu, zapobieganie oraz leczenie chorób, z którymi miał kontakt, ochrona środowiska, dbanie o swoje rośliny, czy zwierzęta i wiele innych zagadnień tym podobnych. Współczesna biologia dotyka dorastającego człowieka w wielu życiowych sytuacjach. Wpływa na kształtowanie się jego postaw i zachowań, krótko mówiąc ma olbrzymi wpływ na jego wychowanie, w tym przypadku, jak w każdym innym, kierowane przez wymienione wyżej osoby i instytucje.

\section{Literatura}

Giereluk-Lubowicz Z., Wychowanie w rodzinie wielkomiejskiej. WSiP, Warszawa 1978. Gordon T., Wychowanie bez porażek. Instytut Wydawniczy Pax, Warszawa 2007.

Kunowski S., Podstawy współczesnej pedagogiki. Wydawnictwo Salezjańskie, Warszawa 1993.

Łовоскі M., АВC Wychowania. Wydawnictwo Uniwersytetu Marii Curie-Skłodowskiej, Lublin 1999.

\footnotetext{
38 I. ŻeBer-DziKowska, J. BARToszczyK, Znaczenie nauczania biologii w kształtowaniu osobowości ucznia. Wydawnictwo Akademii Świętokrzyskiej, Kielce 2007, s. 7.

39 W. ОкоŃ, Słownik Pedagogiczny. Państwowe Wydawnictwo Naukowe, Warszawa 1987, s. 34.
} 
Łовоскі M. (red.), Praca wychowawcza dziećmi i młodzieżą. Wydawnictwo Uniwersytetu Marii Curie-Skłodowskiej, Lublin 1998.

Łовоскі M., Teoria Wychowania w zarysie. Oficyna Wydawnicza „Impuls”, Kraków 2006.

Łовоскі M., W poszukiwaniu skutecznych form wychowania. Wydawnictwa Szkolne i Pedagogiczne, Warszawa 1990.

Łовоскі M., Współdziałanie nauczycieli i rodziców w procesie wychowania. Nasza Księgarnia, Warszawa 1985.

Muszyński H., Rodzina Moralność Wychowanie. Nasza Księgarnia, Warszawa 1971.

Окоќ W., Słownik Pedagogiczny. Państwowe Wydawnictwo Naukowe, Warszawa 1987.

Окоќ W., Wszystko о wychowaniu. Wydawnictwo Akademickie „Żak”, Warszawa 1999.

Pauling P., Szczęśliwe Dzieci, czyli udane wychowanie. Wydawnictwo „Jedność”, Kielce 2000.

Przetacznikowa M., WŁodarski Z., Psychologia Wychowawcza. Państwowe Wydawnictwo Naukowe, Warszawa 1979.

Siemek D., Problemy Wychowawcze Wieku Dorastania. Instytut Wydawniczy Związków Zawodowych, Warszawa 1986.

Spock B., Rothenberg M., Dziecko. Pielęgnowanie i Wychowanie. Wydawnictwo Lekarskie PZWL, Warszawa 1990.

Wall W. D., Wychowanie i Zdrowie Psychiczne. Państwowe Wydawnictwo Naukowe, Warszawa 1960.

ŻEber-Dzikowska I., Bartoszczyк J., Znaczenie nauczania biologii w kształtowaniu osobowości ucznia. Wydawnictwo Akademii Świętokrzyskiej, Kielce 2007.

\title{
What does education in the sphere of Biology mean in people's education?
}

\begin{abstract}
SUMMARY
Schools allow to develop and extend the approaches and attitudes in the social, moral, ideological and religious spheres. The realization of these matters is possible due to the fulfillment of three basic school functions, i.e. didactic, educational and protective. No one should forget that human's education starts already in the period of the childhood. Initially, parents introduce the children to the indispensable problems and matters in their future lives. It takes place in the form of games. They satisfy their growing need of gaining the knowledge, by answering the numerous questions. They develop the knowledge by practical activities to let them gain the experience, that is, organize walks, educational games, and so forth. Then young people begin the school education, which influences, to a large degree, their lives. Then, in the educational process the subject of Biology appears, almost certainly already known thanks to the parents' education. The scientific discipline called Biology is a very important element in the education of people, which is helpful in understanding their own personalities and the surrounding reality. The wide range of biological contents as well as the short reflection on the subject of gaining the knowledge in the range of Biology allows to notice, that this discipline, similarly to other disciplines shapes the personality of young, growing up people. All things considered, however, it differs from disciplines such as history, or mathematics, because it is closely and directly related to the human being and functioning, as the basis of human life. Biology, more considerably and effectively, than different disciplines, makes the students sensible towards the human needs as well as the needs of the nature and its protection.
\end{abstract}

